\section{Response of Retail Lawn Seed Products during Acute Drought and Recovery}

\author{
Florence Breuillin-Sessoms ${ }^{1}$, Dominic P. Petrella ${ }^{1}$, \\ Daniel Sandor ${ }^{2}$, Samuel J. Bauer ${ }^{3}$, and Brian P. Horgan ${ }^{4}$
}

ADDITIONAL INDEX WORDS. fine fescue, green cover, green stability, kentucky bluegrass, mowing height, perennial ryegrass, recovery, tall fescue

Summary. Consumers often have multiple choices when purchasing retail lawn products in stores. In this study, we evaluated the acute drought performance of locally available retail lawn seed products (mixtures or blends) at two mowing heights of 2.5 and 3 inches. We hypothesized that the species present in the products and the height-of-cut differentially influence the drought resistance and recovery of the mixtures and blends. In Fall 2016 and 2017, 28 different products consisting of 25 mixtures and 3 blends of turfgrass seeds were established under a fully automated rainout shelter at the St. Paul campus of the University of Minnesota. The drought treatments lasted for 67 days in 2017, and 52 days in 2018; both the 2017 and 2018 treatments were followed by a recovery period. Data were obtained during acute drought treatments and recovery periods for visual turfgrass quality and green turfgrass cover using digital images of the plots. During the first year, several products displayed higher green stability (or the ability to remain green) at the 3 -inch height-of-cut compared with the 2.5-inch height-of-cut. Products with tall fescue (Schedonorus arundinaceus) and fine fescue (Festuca sp.) as dominant species generally performed better during the drought treatments, whereas an increasing presence of perennial ryegrass (Lolium perenne) and kentucky bluegrass (Poa pratensis) decreased the visual drought performance of the products. During the recovery period, an effect of the interaction between mowing height and the date of data collection on the percentage of green cover was observed: the lower mowing height improved the early recovery of green cover after acute drought. These findings suggest that consumers in the upper midwestern United States and areas with a climate similar climate to that of St. Paul, MN, who are challenged with multiple choices of lawn seed products should choose products containing a higher tall fescue content and adjust their mowing heights to optimize recovery.

$\mathrm{R}$ etail lawn seed products sold in local stores in the upper midwestern United States contain kentucky bluegrass (Poa pratensis), perennial ryegrass (Lolium perenne), tall fescue (Schedonorus arundinaceus), and/or fine fescue species (Festuca sp.). Fast-establishing turfgrass species, like rough bluegrass (Poa trivialis) and annual ryegrass (Lolium perenne multiflorum), may be present in smaller percentages because they decrease weed encroachment through fast germination and establishment or improved shade tolerance (Rajasekar et al., 2006). However, the number and percentage of all these species, and even the cultivars used, vary tremendously between the different available products. According to the Minnesota Department of Agriculture (2021), each product label needs to present the following information: type and cultivar of the seeds; lot number; purity; inert matter and germination percentages; and the presence of noxious weed. Several retail lawn seed products can possess similar species compositions, but the species percentage or even the cultivars used can differ among them. These different products of the same species can respond quite differently when subjected to stresses (Friell et al., 2015).

Turfgrass species mixtures and cultivar blends of the same species encourage a wide range of genetic diversity and plasticity, leading to improved tolerance to biotic and abiotic stresses (Ebdon and Skogley, 1985; Friell et al., 2015). Using mixtures and/or blends helps account for variations in landscape microenvironments, such as sunlight availability, soil physical and chemical properties, seasonal variations in temperature, or even pest resistance. Decades of research involving turfgrass mixtures have been performed to identify which combination of species and their percentages within the mixture can improve turf quality (Hunt and Dunn, 1993; Macolino et al., 2014; RoseFricker et al., 1997), increase wear tolerance (Park et al., 2017; Stier et al., 2005) improve sod strength (Friell et al., 2017), enhance disease resistance (Cutulle et al., 2013), and reduce fertilizer or irrigation requirements (Dunn et al., 2002; Reiter et al., 2017).

Managed turfgrass lawns are often viewed as luxurious, nonessential components of a landscape, and they are sometimes a focal point of input restrictions, especially with irrigation (Ozan and $\mathrm{Al}$ sharif, 2013) during seasonal drought. Recommended best management practices (BMP) to reduce water use on lawns have been proposed, including the use of more refined irrigation practices through sensing technologies (Carrow, 2006), the use of irrigation controllers (Dukes, 2012), submitting lawns to deficit-irrigation strategies (Dacosta and Huang, 2006; Fry and Butler, 1989), and using improved species or cultivars. Increasing the mowing height to improve turfgrass drought resistance is also a recommended BMP for homeowners because a higher height-of-cut will result in deeper root development (Harrison, 1931).

Although the turfgrass species present and the mowing height can alter lawn performance under drought conditions, several studies have focused on studying the effect of the mowing height on the drought resistance of single species (Su et al., 2009) or mixtures (Macolino et al., 2014). However, to

\begin{tabular}{llll}
\hline $\begin{array}{l}\text { Units } \\
\text { To convert U.S. to SI, } \\
\text { multiply by }\end{array}$ & U.S. unit & SI unit & $\begin{array}{l}\text { To convert SI to U.S., } \\
\text { multiply by }\end{array}$ \\
\hline 0.3048 & ft & $\mathrm{m}$ & 3.2808 \\
2.54 & inch(es) & $\mathrm{cm}$ & 0.3937 \\
25.4 & inch(es) & $\mathrm{mm}$ & 0.0394 \\
16.3871 & inch $^{3}$ & $\mathrm{~cm}^{3}$ & 0.0610 \\
48.8243 & lb/1000 $\mathrm{ft}^{2}$ & $\mathrm{~kg} \cdot \mathrm{ha}^{-1}$ & 0.0205 \\
1.1209 & lb/acre & $\mathrm{kg} \cdot \mathrm{ha}^{-1}$ & 0.8922 \\
28.3495 & $\mathrm{oz}$ & $\mathrm{g}$ & 0.0353 \\
$\left({ }^{\circ} \mathrm{F}-32\right) \div 1.8$ & ${ }^{\circ} \mathrm{F}$ & ${ }^{\circ} \mathrm{C}$ & $\left({ }^{\circ} \mathrm{C} \times 1.8\right)+32$ \\
& & &
\end{tabular}


our knowledge, no study has examined the effect of different mowing practices on diverse retail lawn seed products during acute drought stress. Different products with various ratios of drought-tolerant and drought-intolerant species grown together could show disparate drought performance; furthermore, the mowing height may result in interactions that could either increase or decrease drought resistance (Wilman et al., 1998). Therefore, the objectives of this study were to evaluate the drought performance of retail lawn seed products mowed at two different heights-of-cut and to evaluate the ability of these products to recover after acute drought stress.

\section{Material and methods}

ESTABLISHMENT AND TREATMENTS. The 28 retail lawn seed mixtures and blends, hereafter called products, were purchased from local retail stores in the Minneapolis and St. Paul, MN, area during Summer 2016. They were established under a fully automated rainout shelter at the Turfgrass Research, Outreach, and Education Center at the University of Minnesota in St. Paul (Table 1). A total of 10 different species were present among the different products: tall fescue (TF); kentucky bluegrass (KB); creeping red

Received for publication 20 Jan. 2021. Accepted for publication 8 Apr. 2021

Published online 8 June 2021.

${ }^{1}$ University of Minnesota, Department of Horticultural Science, 305 Alderman Hall, 1970 Folwell Avenue, St. Paul, MN 55108

${ }^{2}$ Virginia Polytechnic Institute and State University, School of Plant and Environmental Sciences, 328 Smyth Hall, 185 Ag Quad Lane, Blacksburg, VA 24061

${ }^{3}$ North Central Turfgrass Association, 701 Main Avenue, Fargo, ND 58103

${ }^{4}$ Michigan State University, Department of Plant, Soil and Microbial Sciences, 1066 Bogue Street, East Lansing, MI 48824

This research project was funded by the Metropolitan Council and the Clean Water, Land, and Legacy Amendment.

We are grateful for the assistance of the numerous undergraduates and their tremendous help and acknowledge all members of the Watkins and Horgan groups at the University of Minnesota for their help and discussion on the data analysis. We thank Eric Watkins, Kristine Moncada, and Brian Davis for their review of the manuscript.

F.B.-S. is the corresponding author. E-mail: fsessoms@ umn.edu.

This is an open access article distributed under the CC BY-NC-ND license (https://creativecommons. org/licenses/by-nc-nd/4.0/)

https://doi.org/10.21273/HORTTECH04809-21 fescue (CR; Festuca rubra ssp. rubra); chewings fescue $(\mathrm{CH}$; F. rubra ssp. fallax); hard fescue (HF; Festuca brevipila); sheep fescue (SF; Festuca ovi$n a)$; perennial ryegrass (PR); annual ryegrass $(\mathrm{AR})$; rough bluegrass $(\mathrm{RB})$; and alkaligrass (AK; Puccinellia sp.). All fine fescue species were regrouped into one fine fescue (FF) group. The soil was a Waukegan silt loam (finesilty over sandy or sandy-skeletal, mixed, superactive, mesic Typic Hapludolls). Glyphosate was applied at $2.75 \mathrm{lb} /$ acre before establishment (Roundup PowerMAX; Bayer, Whippany, NJ). The experiments had a split-plot randomized complete block design with three replicates. The mowing height was the main plot factor, and the products were the main subplot factor. For the main plot factor, plots were mowed at either 2.5 inches (low mow) or 3 inches (high mow) using a rotary push mower twice per week starting in spring and during the acute drought and recovery experiment; for each mowing, the clippings were returned. A seeding rate of two pure live seeds per square centimeter was used for all plots. For each product, the seeding weight was calculated based on the 1000 seed weight, percent germination, and inert matter percentage. The seeding weight varied from to 8.82 to $83.22 \mathrm{~g}$ of the product. Subplots $(3.0 \times 3.0$ $\mathrm{ft}$ ) were sown by hand on $16 \mathrm{Sept}$. 2016 for the 2017 trial; they were sown in an adjacent location on 15 Aug. 2017 for the 2018 trial. Plots were fertilized after seeding with a starter fertilizer at a rate of $0.51 \mathrm{lb} /$ $1000 \mathrm{ft}^{2}$ nitrogen, $0.45 \mathrm{lb} / 1000 \mathrm{ft}^{2}$ phosphorous, and $0.43 \mathrm{lb} / 1000 \mathrm{ft}^{2}$ potassium; then, they were covered with a wood fiber blanket (Futerra; Profile Products, Buffalo Grove, IL). Irrigation was applied at 0.10 inches three times per day for a 2 -week period. Thereafter, irrigation was applied at $100 \%$ of evapotranspiration (ET), except during acute drought and recovery periods. Nitrogen fertilizer was applied during establishment, twice in the fall and once in spring, for a total of $2.97 \mathrm{lb} / 1000 \mathrm{ft}^{2}$. Acute drought treatments for 2017 were started 25 May and continued until 30 July $(67 \mathrm{~d})$. The acute drought treatment for 2018 started on 4 June and continued until 25 July ( $52 \mathrm{~d}$ ). The length of these acute drought periods simulated potential seasonal drought that could occur with climate change (Reiter et al., 2017). During the acute drought treatment, the fully automated rainout shelter was programmed to move over the experimental area during each rainfall event and move off the plot area when the rainfall event passed. At the conclusion of the acute drought treatment, the experimental area received a $28-\mathrm{d}$ recovery period during both 2017 and 2018. At the beginning of the recovery period, the experimental area was irrigated with two applications of 1.0 inch of water within $2 \mathrm{~d}$ to re-wet the soil surface that had become very hard. Later, irrigation was programmed to apply 0.50 inches of water twice per week during the recovery period, regardless of rainfall events. During the recovery period, the rainout shelter did not move over the experimental area; therefore, plots also received natural rainfall.

Green COVER. Digital images of the plots were collected weekly during the acute drought treatments and recovery periods. An aluminum light box $\left(3.7\right.$ inch $\left.^{3}\right)$ with four 8.3-inch-long, $6000 \mathrm{~K}$, lithium-ion battery-powered light-emitting diodes (WHQ20-40; Commercial Electric Products, Cleveland, $\mathrm{OH}$ ) was used to illuminate the plot area. A 12.1-megapixel point-andshoot digital camera (PowerShot SXI30IS; Canon, Tokyo, Japan) was used to acquire pictures (manual mode, f/4.0, $1 / 25$, ISO-200, 8-mm focal length) of each plot. Images were subjected to digital image analysis using ImageJ software (version 1.46r; National Institutes of Health, Bethesda, MD) to objectively assess the percentage of green cover (Karcher and Richardson, 2013; Schneider et al., 2012; Zhang et al., 2016) in a modified macro (Soldat et al., 2012).

Turf QUALITY. Visual turf quality (TQ) was rated using the National Turfgrass Evaluation Program (NTEP) scale ranging from 1 to 9 (Morris and Shearman, 2004), where 1 = poor quality (brown, dead, thin/bare soil containing many weeds), $6=$ the minimum acceptable, and $9=$ excellent quality (dense, weed-free, dark color).

Green stability. Green stability was defined as the number of days during which the percentage of green cover was not different at $P<0.05$ from that at the first observation date ( $7 \mathrm{~d}$ after drought treatment initiation). 
Table 1. List of retail lawn seed products, species included \{perennial ryegrass (PR), annual ryegrass (AR), kentucky bluegrass (KB), tall fescue (TF), fine fescue [FF consisting of chewings fescue (CH), creeping red fescue (CR), hard fescue (HF), and sheep fescue (SF)], rough bluegrass (RG), and alkaligrass (AK) \}, and the species present by their percentage of seed weight and seed number in $1.0 \mathrm{~g}(0.035 \mathrm{oz})$ of product.

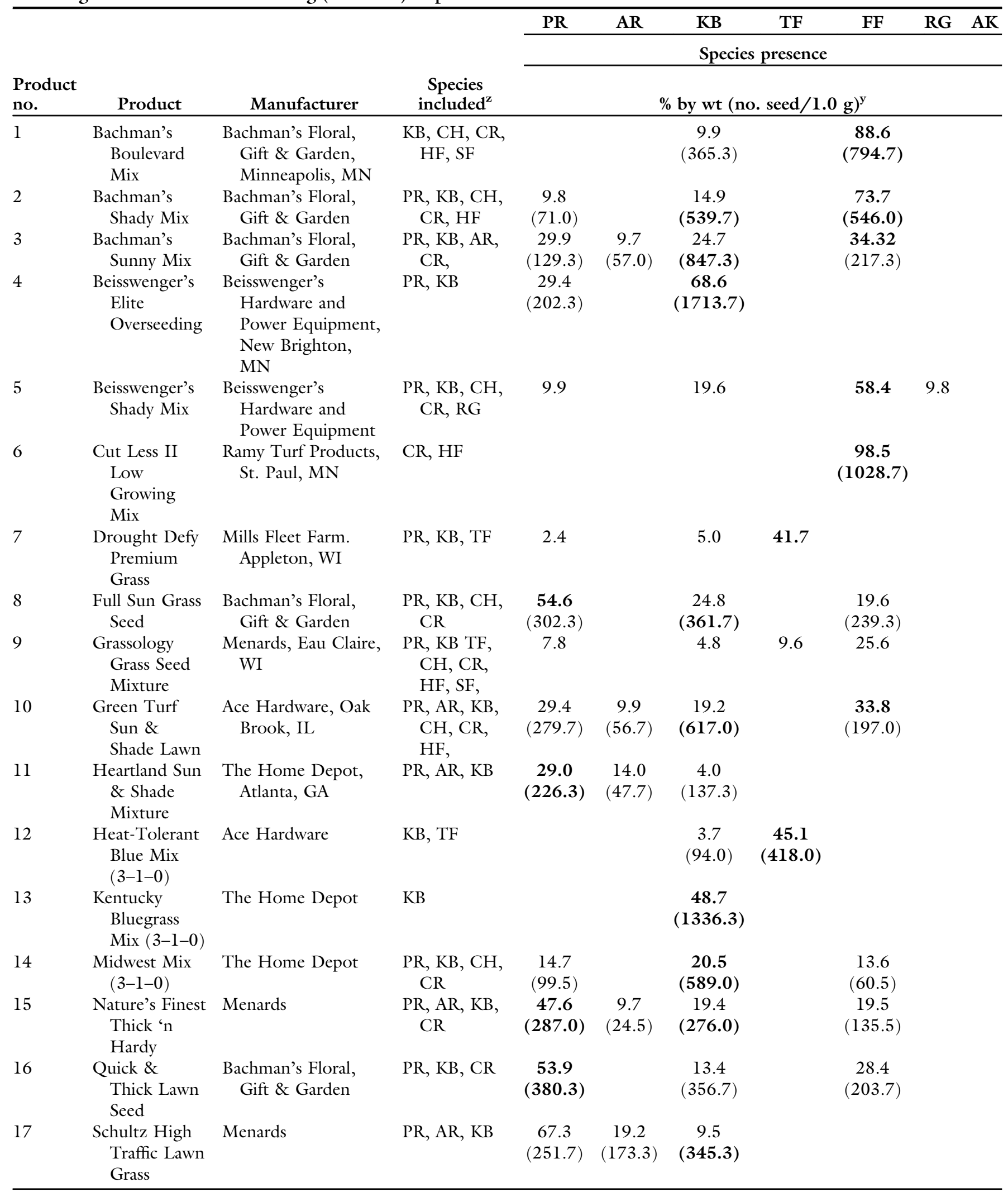


Table 1. (Continued).

\begin{tabular}{|c|c|c|c|c|c|c|c|c|c|c|}
\hline \multirow{3}{*}{$\begin{array}{l}\text { Product } \\
\text { no. }\end{array}$} & \multirow[b]{3}{*}{ Product } & \multirow[b]{3}{*}{ Manufacturer } & \multirow{3}{*}{$\begin{array}{c}\text { Species } \\
\text { included }^{\mathrm{z}}\end{array}$} & PR & AR & KB & TF & FF & RG & $\mathrm{AK}$ \\
\hline & & & & \multicolumn{7}{|c|}{ Species presence } \\
\hline & & & & \multicolumn{7}{|c|}{$\%$ by wt (no. seed $/ 1.0 \mathrm{~g})^{\mathrm{y}}$} \\
\hline 18 & $\begin{array}{l}\text { Schultz Sun \& } \\
\text { Shade Mix } \\
\text { Grass }\end{array}$ & Menards & $\begin{array}{l}\mathrm{PR}, \mathrm{AR}, \mathrm{KB}, \\
\mathrm{CH}, \mathrm{CR}, \\
\mathrm{HF}\end{array}$ & $\begin{array}{c}33.36 \\
(132.0)\end{array}$ & $\begin{array}{c}14.4 \\
(55.0)\end{array}$ & $\begin{array}{c}18.3 \\
(493.0)\end{array}$ & & $\begin{array}{c}26.8 \\
(260.0)\end{array}$ & & \\
\hline 19 & $\begin{array}{c}\text { Smart Seed } \\
\text { Fescue/ } \\
\text { Bluegrass }\end{array}$ & The Home Depot & $\mathrm{KB}, \mathrm{TF}$ & & & $\begin{array}{c}10.0 \\
(161.3)\end{array}$ & $\begin{array}{c}88.0 \\
(380.0)\end{array}$ & & & \\
\hline 20 & $\begin{array}{l}\text { Smart Seed } \\
\text { Midwest } \\
\text { Mix }\end{array}$ & The Home Depot & $\mathrm{PR}, \mathrm{KB}, \mathrm{CH}$ & $\begin{array}{c}66.0 \\
(327.7)\end{array}$ & & $\begin{array}{c}16.0 \\
(471.0)\end{array}$ & & $\begin{array}{c}16.0 \\
(167.3)\end{array}$ & & \\
\hline 21 & $\begin{array}{l}\text { Smart Seed } \\
\text { Sun \& } \\
\text { Shade Mix }\end{array}$ & The Home Depot & $\begin{array}{l}\mathrm{KB}, \mathrm{TF} \mathrm{CH}, \\
\mathrm{CR}\end{array}$ & & & $\begin{array}{c}10.0 \\
(202.7)\end{array}$ & $\begin{array}{c}74.0 \\
(346.0)\end{array}$ & $\begin{array}{c}14.0 \\
(143.3)\end{array}$ & & \\
\hline 22 & $\begin{array}{l}\text { Sun \& Shade } \\
\quad \operatorname{Mix}(3-1-0)\end{array}$ & The Home Depot & $\mathrm{PR}, \mathrm{KB}, \mathrm{CR}$ & $\begin{array}{c}20.0 \\
(216.3)\end{array}$ & & $\begin{array}{c}9.3 \\
(193.3)\end{array}$ & & $\begin{array}{c}19.5 \\
(133.0)\end{array}$ & & \\
\hline 23 & $\begin{array}{l}\text { Superior Blue } \\
\text { Blend } \\
\text { Mixture }\end{array}$ & Mills Fleet Farm & $\mathrm{KB}$ & & & $\begin{array}{c}73.5 \\
(2068.0)\end{array}$ & & & & \\
\hline 24 & $\begin{array}{l}\text { Superior } \\
\text { Northern } \\
\text { Lawn } \\
\text { Mixture }\end{array}$ & Mills Fleet Farm & $\mathrm{PR}, \mathrm{KB}, \mathrm{CR}$ & $\begin{array}{c}\mathbf{5 8 . 9} \\
(344.3)\end{array}$ & & $\begin{array}{c}14.8 \\
(\mathbf{5 5 8 . 7})\end{array}$ & & $\begin{array}{c}10.0 \\
(57.7)\end{array}$ & & \\
\hline 25 & Tuff Turf Mix & Ramy Turf Products & $\mathrm{KB}, \mathrm{TF}$ & & & $\begin{array}{c}8.5 \\
(50.7)\end{array}$ & $\begin{array}{c}89.8 \\
(411.0)\end{array}$ & & & \\
\hline 26 & $\begin{array}{l}\text { Turf Champ } \\
\text { Sunny Grass } \\
\text { Seed }\end{array}$ & Menards & $\mathrm{PR}, \mathrm{AR}, \mathrm{KB}$ & $\begin{array}{c}38.62 \\
(300.7)\end{array}$ & $\begin{array}{l}37.97 \\
(55.0)\end{array}$ & $\begin{array}{c}17.08 \\
(337.7)\end{array}$ & & & & \\
\hline 27 & $\begin{array}{l}\text { Vigoro } \\
\text { Curbside } \\
\text { Mix \& } \\
\text { Perfect }\end{array}$ & The Home Depot & $\begin{array}{l}\mathrm{PR}, \mathrm{AR}, \mathrm{RG}, \\
\quad \mathrm{AK}\end{array}$ & 39.1 & 19.7 & & & & 9.8 & 29.6 \\
\hline 28 & $\begin{array}{l}\text { Vigoro Tall } \\
\text { Fescue Grass } \\
\text { Seed }\end{array}$ & The Home Depot & $\mathrm{TF}$ & & & & $\begin{array}{c}98.4 \\
(461.3)\end{array}$ & & & \\
\hline
\end{tabular}

${ }^{\mathrm{z}}$ Number of species indicated in the packaging of each product.

${ }^{y}$ Numbers in bold indicate the dominant species based on the percentage of seed by weight or in $1.0 \mathrm{~g}$ of the product.

A higher green stability value indicated that the plots stayed green for a longer period of time during acute drought treatment.

SEed NUMber PER SPECIES. For each product, $1.0 \mathrm{~g}$ of seed was weighed (three times) and the species were separated using the seed anatomy specific to each species (Christians, 2007). Certain species (TF and PR) could not be differentiated by seed anatomy; therefore, the species composition at the time of seeding of products \#5, \#7, \#9, and \#27 could not be evaluated.

Statistical analysis. All statistical analyses were performed using JMP software (JMP PRO version 13; SAS Institute, Cary, NC). The percentage of green cover data and TQ data were subjected to an analysis of variance
(ANOVA) using a mixed model with a repeated structure. Experimental years (2017 and 2018) were analyzed independently. Mowing height, turfgrass products, and time were treated as fixed effects. Replicates and the interaction between the block and fixed effects were treated as random effects. An $\operatorname{AR}(1)$ covariance model was used for the repeated structure. Tukey's honestly significant difference test was used for means comparisons. The results of this mixed model and means comparison allowed for the determination of the green stability for each product.

The effects of mowing height and product on the final percentage of the green cover time point during the acute drought treatment were analyzed using an ANOVA, and Student's $t$ test was used for means comparison. A similar analysis was performed for the effects of the mowing height and product on the final percentage of the green cover time point during the recovery period.

The correlation analysis and correlation coefficients were estimated for the final percentage of the green cover time point during the acute drought treatment, species number, percentage of green cover after $7 \mathrm{~d}$ after drought treatment initiation, and green stability.

\section{Results and discussion}

The species and cultivars that were present, the number of species represented, and their ratios within the products varied greatly between the different retail lawn seed products 
(Table 1). A total of 16 evaluated products possessed FF species in their mix, but only two products had FF as the most abundant species (\#1 and \#6) at seeding (Table 1 ). One product (\#2) presented $\mathrm{FF}$ and $\mathrm{KB}$ as dominant species at seeding $(<5 \%$ difference between the two seed numbers). Among the seven products that contained TF, only four products had TF as the most abundant at seeding (\#12, \#19, \#21, cultivars (\#28). All 25 products contained $\mathrm{KB}$, and only 10 were dominated by $\mathrm{KB}$ at seeding $(\# 3, \# 4, \# 8, \# 10$, $\# 14, \# 17, \# 18, \# 20, \# 24$, and \#26), whereas two were blends of $\mathrm{KB}$ cultivars (\#13 and \#23). A total of 19 products possessed $\mathrm{PR}$, but only three possessed this species as the most abundant one at seeding (\#11, \#16, and \#22). Only one product possessed similar numbers of $\mathrm{KB}$ and $\mathrm{PR}$ seeds at seeding (\#15). Interestingly, several products presented the same mixture composition at seeding (Table 1 ), but the species presence varied tremendously between products. For example, products \#2, \#8, \#14, \#16, \#20, $\# 22$, and \#24 were all mixtures comprising $\mathrm{PR}, \mathrm{KB}$, and FF species; however, some products were dominated at seeding by $\mathrm{FF}(\# 2), \mathrm{KB}(\# 8, \# 14$, $\# 20$, and \#24), or PR (\#16 and \#22).

In 2017, the average daily air temperatures for late May/June and July during acute drought treatment and \#25), and one was a blend of TF

were 68.5 and $72.1^{\circ} \mathrm{F}$, respectively; in 2018 , the average daily air temperatures for June and July were 72.9 and $76.6{ }^{\circ} \mathrm{F}$, respectively. During the recovery period in August, the average daily air temperatures were $65.5{ }^{\circ} \mathrm{F}$ (2017) and $74.3^{\circ} \mathrm{F}$ (2018). During the recovery period, plots were exposed to natural rainfall and the $\mathrm{cu}^{-}$ mulative precipitation amounts were 0.89 inches for 2017 and 0.29 inches for 2018. Overall, the 2017 experiment was performed during a cooler summer, and more precipitation occurred during the recovery period compared with 2018.

For both years, there were significant effects of the interactions among the products, mowing heights, and time points (hereafter referred to as time) during the acute drought treatment on the percentage of green cover (Table 2). The average percentage of green cover for the low mow treatment stayed significantly lower compared with the high mow treatment during $49 \mathrm{~d}$ of acute drought for 2017 , and during $36 \mathrm{~d}$ of acute drought for 2018 (Fig. $1 \mathrm{~A}$ and B). Similar interactions among the products, mowing height, and time were observed for the TQ, but only in 2017 (Table 2). The average TQ was significantly lower for the low mow treatment than for the high mow treatment during $49 \mathrm{~d}$ of drought in 2017 (Fig. 1C). An effect of time was still observed for the average TQ in

Table 2. Results of the mixed-model analysis of the effects of lawn seed products (28 products tested described in Table 1 ), mowing heights $\{\mathrm{MH}$ [ 3 inches $(7.62$ $\mathrm{cm}$ ) and 2.5 inches $(6.35 \mathrm{~cm})]\}$, time points (Time), and their interactions on the percentage green cover and turf quality (TQ) during acute drought $(67 \mathrm{~d}$ in 2017 and $52 \mathrm{~d}$ in 2018 with no irrigation or precipitation) and recovery (28 d with scheduled irrigation and natural precipitation) experiments.

\begin{tabular}{|c|c|c|c|c|c|c|}
\hline \multirow[b]{4}{*}{ Effect } & \multicolumn{4}{|c|}{ Green cover $(\%)^{\mathrm{z}}$} & \multirow{2}{*}{\multicolumn{2}{|c|}{$\begin{array}{c}\mathrm{TQ}^{\mathrm{y}} \\
\text { Acute drought }\end{array}$}} \\
\hline & \multicolumn{2}{|c|}{ Acute drought } & \multicolumn{2}{|c|}{ Recovery } & & \\
\hline & 2017 & 2018 & 2017 & 2018 & 2017 & 2018 \\
\hline & \multicolumn{6}{|c|}{$P>\mathrm{F}$} \\
\hline Product & $* * *$ & $* * *$ & $* * *$ & $* * *$ & $* * *$ & $* * *$ \\
\hline $\mathrm{MH}$ & $* * *$ & $* * *$ & 0.6 & $* * *$ & $* * *$ & * \\
\hline Time & $* * *$ & $* * *$ & *** & $* * *$ & $* * *$ & $* * *$ \\
\hline Product $\times \mathrm{MH}$ & * & 0.1 & 0.4 & 0.2 & 0.3 & 0.4 \\
\hline Product $\times$ time & $* * *$ & $* * *$ & $* * *$ & $* * *$ & $* * *$ & $* * *$ \\
\hline $\mathrm{MH} \times$ time & $* * *$ & $* * *$ & $* * *$ & $* * *$ & $* * *$ & 0.11 \\
\hline Product $\times \mathrm{MH} \times$ time & * & 0.1 & 0.2 & 0.1 & ** & 0.7 \\
\hline
\end{tabular}

${ }^{\mathrm{z}}$ Digital images of the plots were collected weekly during the acute drought and recovery experiments to estimate the percentage of green cover.

${ }^{\mathrm{y}} \mathrm{TQ}$ was rated weekly during the acute drought treatment using a scale of 1 to $9(1=$ poor quality and $9=$ excellent quality).

*,**,***Significant at $P<0.05,0.01$, or 0.001 , respectively, according to Tukey's honestly significant difference test.
2018 (Table 2), and the TQ decreased similarly with the two mowing height treatments (Fig. 1D).

The repeated measures analysis was also used to estimate the green stability of each product during the acute drought treatment for both mowing heights. For both years, no significant difference was observed between the average green stability [2017 high mow green stability $=39.3$ and 2017 low mow green stability $=35.1$, nonsignificant at $P<0.05 ; 2018$ high mow green stability $=25.25$ and 2017 low mow green stability $=25.64$, nonsignificant at $P<0.05$ ]. However, during 2017, 19 products had higher green stability with the high mow treatment than with the low mow treatment, four products had higher green stability with the low mow treatment, and four had the same green stability (Fig. 2A). In 2018, only seven products had higher green stability with the high mow treatment, 12 had similar green stability with both mowing heights, and seven had higher green stability with the low mow treatment (Fig. 2B). These observed differences between the two years could have resulted from the warmer temperatures that may have accentuated the negative effects of drought on the products.

Products containing TF as the dominant species at seeding had the longest green stability, ranging between 42 and $56 \mathrm{~d}$ and between 36 and $44 \mathrm{~d}$ during 2017 and 2018, respectively (Fig. 2A and B). The green stability of TF blends ranged between 42 and $49 \mathrm{~d}$ and between 36 and $44 \mathrm{~d}$ during 2017 and 2018, respectively. Products with $\mathrm{KB}$ as the dominant species at seeding displayed green stability ranging between 29 and $35 \mathrm{~d}$ and between 7 and $36 \mathrm{~d}$ in 2017 and 2018, respectively. The two blends (\#13 and \#23) of KB performed better than the mixtures during 2017, but this trend was not consistent during 2018. The green stability of PR-dominated products varied between $29 \mathrm{~d}$ and $35 \mathrm{~d}$ for 2017; however, it varied between 14 and $28 \mathrm{~d}$ in 2018. Product 15 had a similar amount of PR and KB at seeding, but the presence of $\mathrm{KB}$ did not improve the product green stability, which ranged between 21 and $35 \mathrm{~d}$ in 2017, and was $14 \mathrm{~d}$ in 2018.

With our experimental setup, 16 products possessed FF, but only two of those were dominated by FF at seeding. In 2017, the green stability of 
A

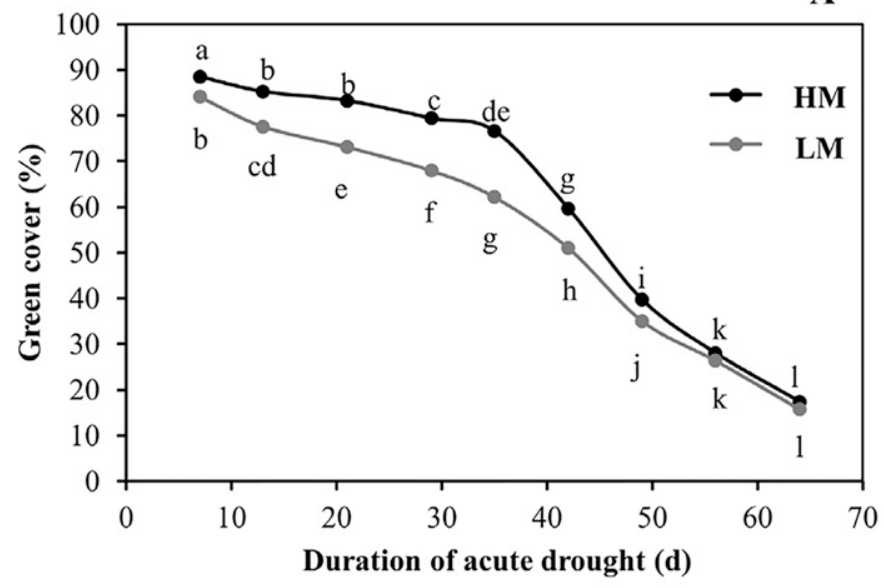

C

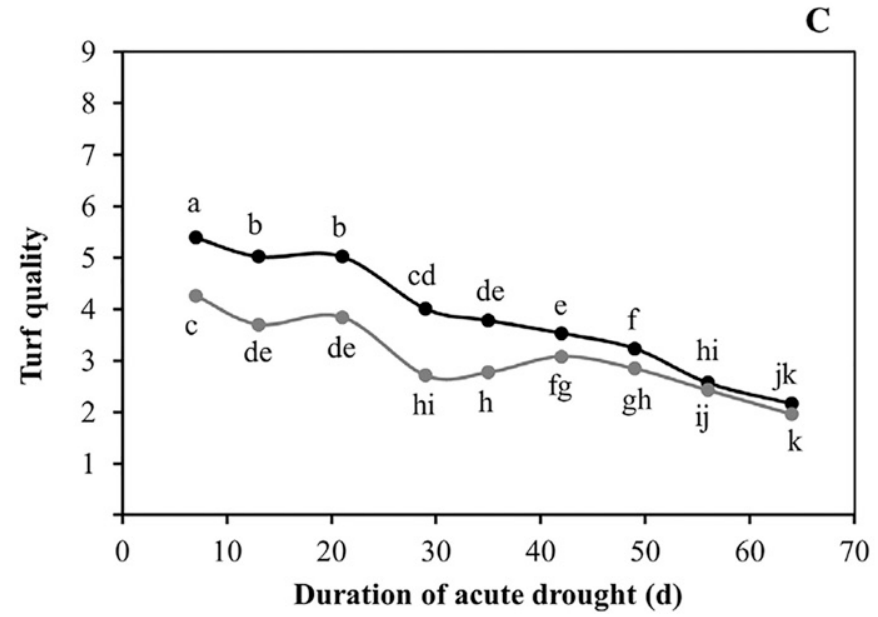

B

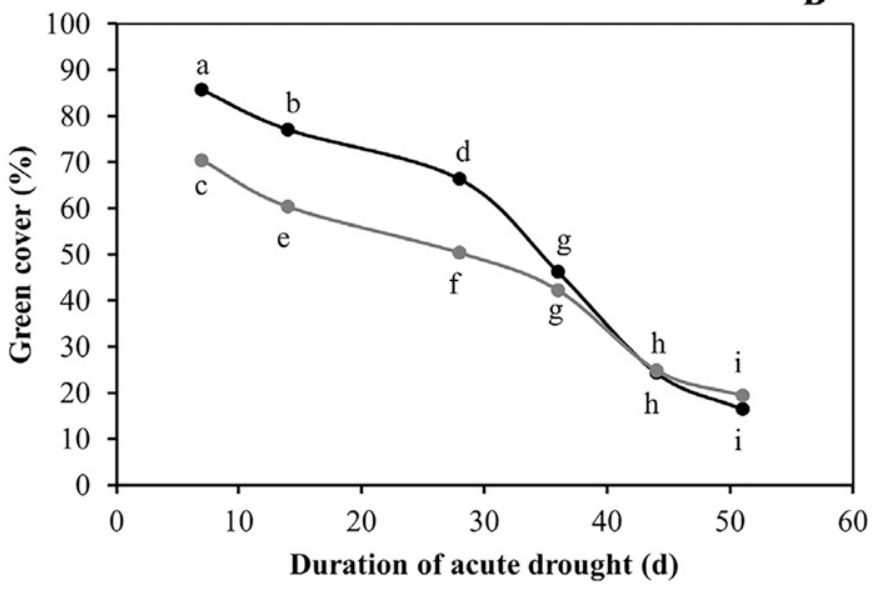

D

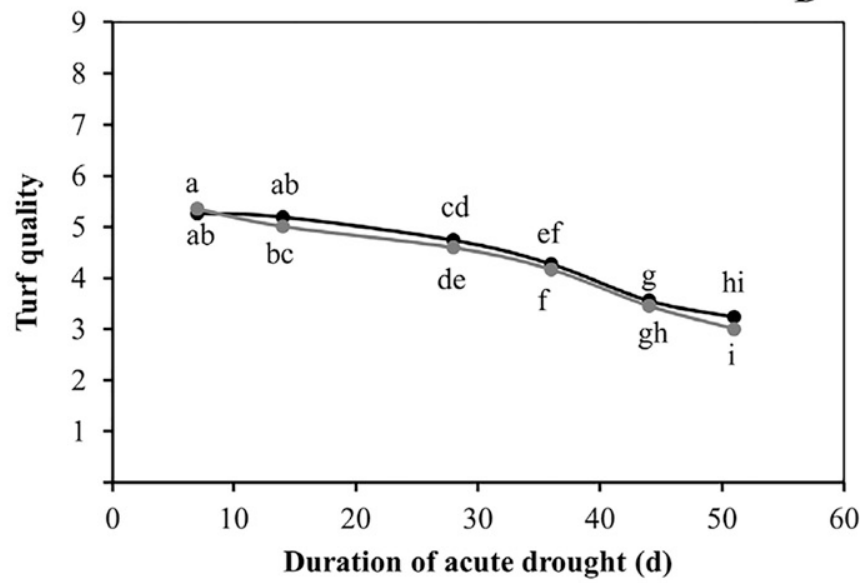

Fig. 1. Percentage of green cover and turf quality (TQ) across all lawn seed products (described in Table 1 ) observed with the high mow (HM; 3 inches; $7.62 \mathrm{~cm}$ ) and low mow (LM; 2.5 inches; $6.35 \mathrm{~cm}$ ) treatments during 2017 (A and C) and 2018 (B and D), and with the acute drought treatment (67 d in 2017 and $52 \mathrm{~d}$ in 2018 with no precipitation). Digital images of the plots were collected weekly during the acute drought treatment to estimate the percentage of green cover. The TQ was rated using a scale of 1 to $9(1=$ poor quality and $9=$ excellent quality). Different letters indicate a difference between the two mowing heights and time points at $P<0.05$ according to Tukey's honestly significant test.

these FF-dominated products ranged from 42 to $56 \mathrm{~d}$; however, in 2018, their green stability ranged between 28 and $51 \mathrm{~d}$. The FF in products dominated by $\mathrm{KB}(\# 3, \# 8, \# 10, \# 14, \# 18$, and \#24), by PR (\#16 and \#22), and by PR and KB (\#15) displayed lower green stability. Furthermore, product \#2 was dominated by $\mathrm{FF}$ and $\mathrm{KB}$ at seeding and showed lower green stability during both years. These observations indicated that the presence of FF in retail lawn seed products does not ensure long-lasting turf performance during seasonal drought. The observed decrease in FF green stability between 2017 and 2018 could have resulted from the higher temperatures during the acute drought in 2018 compared with those during 2017. Previous studies have demonstrated that red fescues, especially slender creeping red fescue (F. rubra ssp. littoralis) perform better than HF and SF in heat stress environments when grown in field-type soil (Breuillin-Sessoms and Watkins, 2020). The authors also observed variations in the response of cultivars of the same species to heat stress (Breuillin-Sessoms and Watkins, 2020). Product \#l contained HF and SF, and product \#6 contained HF, possibly explaining why these two products did not perform as well during the 2018 acute drought treatment.

In summary, products containing TF or FF as a dominant species at seeding displayed the best green stability for both mowing heights, whereas KBand PR-dominant products at seeding presented lower green stability. Beard (1969) indicated that TF and PR exhibited intermediate and poor winter hardiness relative to the winter-hardy $\mathrm{KB}$. However, the recent research of Dierking et al. (2012) showed a large range of freezing tolerance among TF genotypes. Hence, newer TF cultivars used in retail lawn seed products could be more winter-hardy than expected.

For cool-season turfgrasses, TF and $\mathrm{KB}$ have been shown to demonstrate different drought-resistance mechanisms (Bonos and Murphy, 1999; Richardson et al., 2009). During drought, TF exhibits drought-avoidance characteristics and can stabilize its photosynthetic rates, maintain its stomatal conductance, and exhibit reduced leaf senescence because of its deeper root system (Huang and Gao, 2000; Huang et al., 2014). Therefore, products with an increased proportion of TF would 

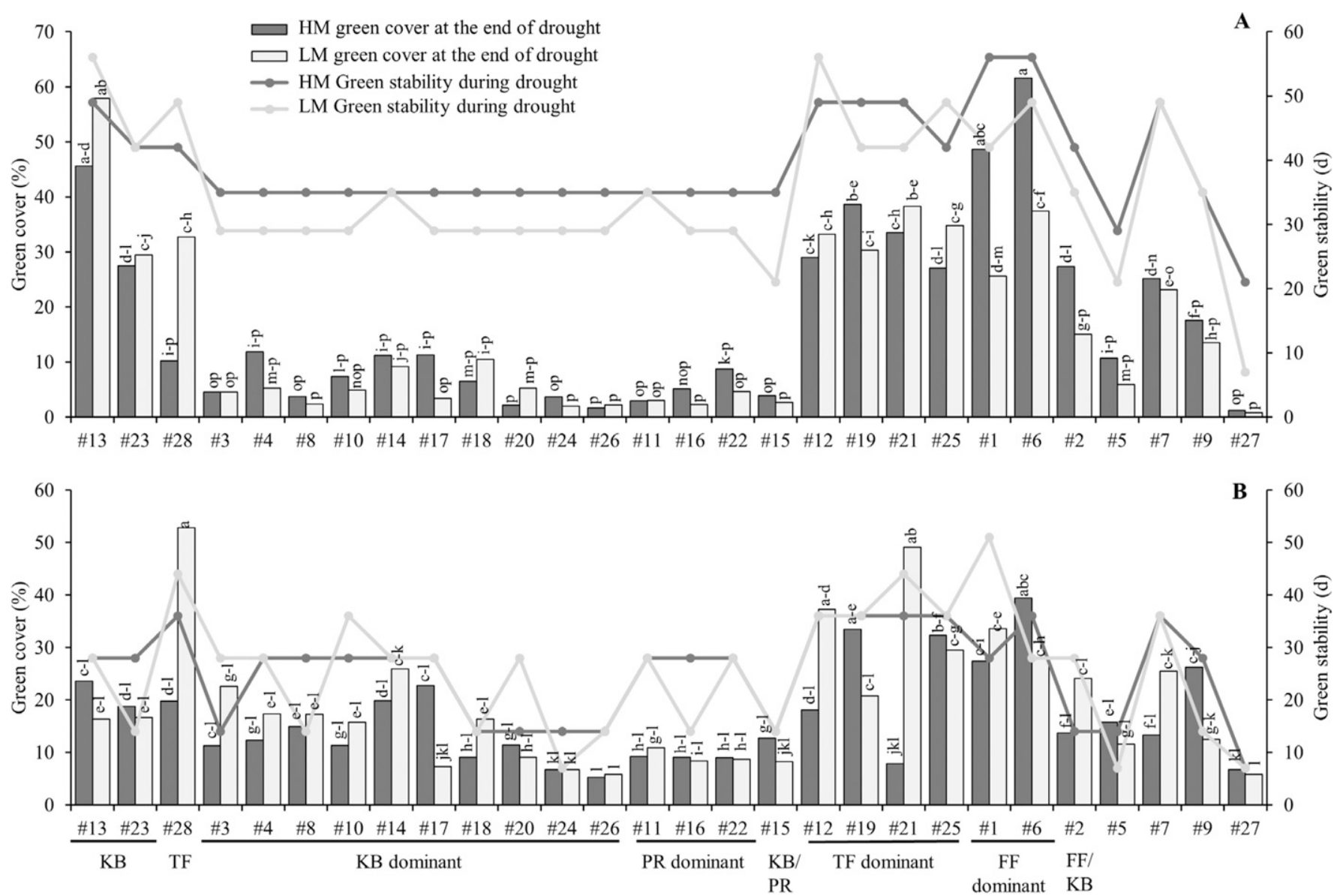

Fig. 2. Percentage of green cover at the end of the acute drought treatment $(67 \mathrm{~d}$ in 2017 and $52 \mathrm{~d}$ in 2018 with no precipitation) and green stability across all lawn seed products (described in Table 1 ) observed with the high mow (HM; 3 inches; $7.62 \mathrm{~cm}$ ) and low mow (LM; 2.5 inches; $6.35 \mathrm{~cm}$ ) treatments during 2017 (A) and 2018 (B). Digital images of the plots were collected weekly during the acute drought treatment to estimate the percentage of green cover. Different letters indicate a difference between the two mowing heights and time points at $P<0.05$ according to Student's $t$ test. Green stability was defined as the number of days when the percentage of green cover was not different from the percentage of green cover $7 \mathrm{~d}$ after drought treatment initiation at $P<0.05$. A higher green stability value indicated that the plots stayed green for a longer period of time during acute drought treatment. The dominant species (species presenting the highest number of seeds at seeding) were kentucky bluegrass (KB), tall fescue (TF), perennial ryegrass (PR), and fine fescue (FF).

appear greener for a longer duration (higher green stability) compared with other cool-season turfgrasses. However, $\mathrm{KB}$ has been shown to exhibit a drought-escape strategy by undergoing dormancy during drought associated with summer temperatures (Domenghini et al., 2013); plant leaves senesce, but meristematic regions and rhizomes survive and grow again when water is available (Huang et al., 2014). The highest temperature observed in 2018 could have accelerated the drought-escape mechanisms of $\mathrm{KB}$, resulting in the lower green stability observed in 2018 for the KB-dominant products. Furthermore, all of the $\mathrm{KB}$-dominant products contained PR. Perennial ryegrass is often used in mixtures because of its ability to germinate and establish quickly $(<5 \mathrm{~d})$, thereby reducing the germination and development of weeds while the other turfgrass species are germinating (Proctor et al., 2015). Unfortunately, PR is not characterized by its ability to perform well in drought (Franca et al., 1998; Rajasekar et al., 2006), and our results showed the same trend. In fact, our results (Fig. 2) showed that most products with PR possess lower green stability and a lower percentage of green cover at the end of the acute drought treatment (with the exception of \#2 and \#7). The presence of PR in retail lawn seed products may decrease the ability to withstand long periods of drought. In addition to its low drought tolerance, PR is generally susceptible to cold stress. Homeowners, should not consider PR-dominant products for long-term lawn establishment in areas with cold winters.
The FF group comprising HF, $\mathrm{SF}, \mathrm{CH}$, and CR displayed various responses to drought stress, but their mechanisms are not fully understood (Wang et al., 2017). These species are thought to be drought-tolerant because of slower growth (Ruemmele et al., 2003). Despite their phenotypic similarities, the different FF species can display very different levels of tolerance to biotic and abiotic stresses (Ruemmele et al., 2003; Wang et al., 2017). Therefore, the response of FF products could vary in function of the species and also the proportions used in the product (Friell et al., 2015).

The mowing height is known to affect the ability of turfgrass plants to produce new leaves and tillers. Recurrent mowing at lower cutting heights reduces the leaf area, resulting in lower 
photosynthetic rates and provoking constant carbon reallocation to shoots (Jones et al., 2017; Liu and Huang, 2003). During the spring establishment period, plots mowed at a lower height may have had lower overall rates of carbon fixation and storage, thus predisposing them to drought stress. Furthermore, heat and drought negatively affect levels of photosynthesis (Chaves et al., 2009), thereby forcing plants to reallocate carbon reserves from carbon sinks and resulting in reduced tiller development. This constant shift in resource allocation (during spring establishment and drought period) for the plots with lower heightsof-cut could explain the reduced green stability observed in certain plots compared with that of plots that received high mow treatments.

At the end of the acute drought treatment, the average percentage green cover and TQ were not different at $P<0.05$ with the low mow and high mow treatments (Fig. $1 A$ and $B$ ). However, the final percentage of green cover data pointed toward significant variations between the products for each mowing height (Fig. 2A and B). A further analysis revealed a strong and significant positive correlation between the final percentage of green cover at the end of the acute drought treatment and the green stability for each mowing height and each year (Table 3 ). These results indicate that a product with longer green stability would possess a higher percentage of green cover at the end of the acute drought. Further correlation analyses revealed that the percentage of green cover after $7 \mathrm{~d}$ after drought treatment initiation did not exhibit a significant correlation with the percentage of green cover at the end of the acute drought treatment for both mowing heights and years (Table 3). These results imply that the percentage of green cover $7 \mathrm{~d}$ after drought treatment initiation does not indicate the success of a product during a long period of drought.

Mixtures are used for their plasticity in response to different stresses (Friell et al., 2015). The insurance hypothesis (Yachi and Loreau, 1999) would indicate that mixtures with a higher number of species have greater resistance to stress, here drought, because some species perform better during the stress and others fail. For the 28 products tested, the number of species present within products ranged from one (for the blends) to seven (Table 1). The absence of a significant correlation with the final percentage of green cover at the end of the acute drought treatment and the number of species (Table 3 ) does not support the insurance hypothesis for retail lawn seed products. Our findings suggest that consumers who want to establish lawns that perform better during drought should not choose a product based on the species number labeled on the packaging. These results of the drought experiments indicate the importance of certain species and the importance of the species composition at seeding for improved drought performance.

During this study, all products, regardless of mowing height, were able to recuperate similarly by the end of the recovery period; however, the percentage of green cover at the end

Table 3. Pearson correlations coefficients of the final percentage of green cover at the end of the acute drought treatment $(67 \mathrm{~d}$ in 2017 and $52 \mathrm{~d}$ in 2018 with no irrigation or precipitation), number of species, percentage of green cover $7 \mathrm{~d}$ after drought treatment initiation $\left(T_{7}\right.$ green cover), and green stability for all lawn seed products. Pearson correlations coefficients are presented for two mowing heights [HM, 3 inches $(7.62 \mathrm{~cm})$ and $L M, 2.5$ inches $(6.35 \mathrm{~cm})]$ during 2017 and 2018.

\begin{tabular}{|c|c|c|c|c|}
\hline Mowing ht & $\mathbf{Y r}$ & Species no. ${ }^{z}$ & T7 green cover $(\%)^{y}$ & Green stability $^{\mathrm{x}}$ \\
\hline \multirow[t]{2}{*}{ HM } & 2017 & $-0.23 \mathrm{NS}$ & $-0.02 \mathrm{NS}$ & $0.89 * * *$ \\
\hline & 2018 & $-0.23 \mathrm{NS}$ & $0.09 \mathrm{NS}$ & $0.57 * *$ \\
\hline \multirow[t]{2}{*}{ LM } & 2017 & $-0.42 *$ & $-0.64 * *$ & $0.87 * * *$ \\
\hline & 2018 & $-0.19 \mathrm{NS}$ & $0.32 \mathrm{NS}$ & $0.75^{* * *}$ \\
\hline
\end{tabular}

${ }^{\mathrm{z}}$ Number of species indicated on the packaging of each product.

${ }^{y}$ Digital images of the plots were collected weekly during acute drought and recovery experiments to estimate the percentage of green cover.

${ }^{\mathrm{x}}$ Green stability $=$ number of days when the percentage of green cover was not different from the percentage of green cover $7 \mathrm{~d}$ after drought treatment initiation at $P<0.05$.

Ns, *,**,***Nonsignificant or significant at $P<0.05,0.01$, or 0.001 , respectively
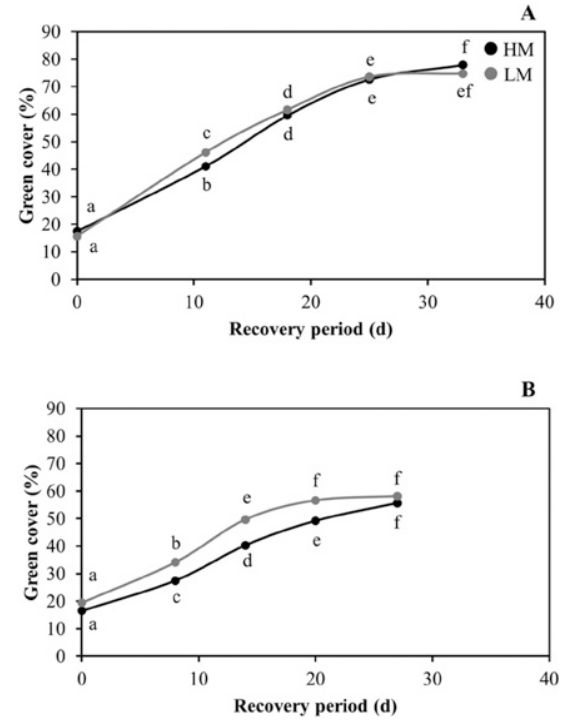

Fig. 3. Percentage of green cover across all lawn seed products (described in Table 1) observed with the high mow (HM; 3 inches; 7.62 $\mathrm{cm})$ and low mow (LM; 2.5 inches; $6.35 \mathrm{~cm}$ ) treatments during 2017 (A) and $2018(\mathrm{~B})$, and during the recovery period (28 d with scheduled irrigation and natural precipitation). Digital images of the plots were collected weekly during recovery to estimate the percentage of green cover. Different letters indicate a difference between the two mowing heights and time points at $P<0.05$ according to Tukey's honestly significant test.

of the recovery period during 2018 was lower than that during 2017 (Fig. 3, Table 4). Summer 2018 was characterized by higher temperatures and lower precipitation compared with Summer 2017, which potentially led to the observed differences between 2017 and 2018. No differences between products and mowing treatments at the end of the recovery period were observed; however, low mow treatments did result in the earlier observation of green than high mow treatments (Fig. 3). This difference could be explained by the fact that plots with higher mowing heights had greater amounts of senesced leaf tissue still present, whereas plots mowed at lower mowing heights would have had most of the senesced tissues removed. Therefore, based on the results of this study, aesthetic recovery from drought could be improved by mowing at a lower height at least once near the beginning of the recovery period to help remove senesced leaf tissue. 
Table 4. Average percentage of green cover for each lawn seed product dominated by different species at seeding [kentucky bluegrass (KB), tall fescue (TF), perennial ryegrass (PR), and fine fescue (FF)] at the end of the recovery period (28 d with scheduled irrigation and natural precipitation) for 2017 and 2018 , using two different mowing heights [HM, 3 inches $(7.62 \mathrm{~cm})$ and LM, 2.5 inches $(6.35 \mathrm{~cm})]$.

\begin{tabular}{|c|c|c|c|c|c|}
\hline \multirow[b]{3}{*}{$\begin{array}{l}\text { Dominant } \\
\text { species }^{\mathrm{z}}\end{array}$} & \multirow[b]{3}{*}{$\begin{array}{c}\text { Product } \\
\text { no. }\end{array}$} & \multicolumn{4}{|c|}{ Green cover $(\%)^{x}$} \\
\hline & & \multicolumn{2}{|c|}{$2017^{\mathrm{w}}$} & \multicolumn{2}{|c|}{$2018^{v}$} \\
\hline & & HM & LM & HM & LM \\
\hline \multirow[t]{2}{*}{ KB blend } & 13 & 83.9 a-d & $84.7 \mathrm{abc}$ & $66.8 \mathrm{a}-\mathrm{f}$ & $50.8 \mathrm{~m}-\mathrm{q}$ \\
\hline & 23 & $85.9 \mathrm{ab}$ & $70.6 \mathrm{o}-\mathrm{t}$ & 67.7 a-e & $58.4 \mathrm{c}-\mathrm{p}$ \\
\hline TF blend & 28 & $78.9 \mathrm{c}-1$ & $81.2 \mathrm{~b}-\mathrm{h}$ & $61.0 \mathrm{c}-\mathrm{O}$ & $76.0 \mathrm{ab}$ \\
\hline \multirow[t]{10}{*}{$\mathrm{KB}$ dominant } & 3 & $78.5 \mathrm{c}-\mathrm{m}$ & $76.45 \mathrm{e}-\mathrm{p}$ & $47.94 \mathrm{opq}$ & $57.18 \mathrm{~d}-\mathrm{q}$ \\
\hline & 4 & $81.21-\mathrm{t}$ & $79.2 \mathrm{tu}$ & $72.0 \mathrm{abc}$ & $78.5 \mathrm{a}$ \\
\hline & 8 & $72.4 \mathrm{~b}-\mathrm{i}$ & $66.5 \mathrm{hi}$ & $44.1 \mathrm{q}$ & $51.9 \mathrm{k}-\mathrm{q}$ \\
\hline & 10 & $83.6 \mathrm{a}-\mathrm{d}$ & $77.9 \mathrm{c}-\mathrm{n}$ & $56.3 \mathrm{e}-\mathrm{q}$ & $65.8 \mathrm{a}-\mathrm{i}$ \\
\hline & 14 & $74.3 \mathrm{~h}-\mathrm{s}$ & $74.1 \mathrm{i}-\mathrm{s}$ & 48.9 opq & $56.5 \mathrm{e}-\mathrm{q}$ \\
\hline & 17 & $77.4 \mathrm{~d}-\mathrm{o}$ & $71.7 \mathrm{~m}-\mathrm{t}$ & $50.2 \mathrm{~m}-\mathrm{q}$ & $52.2 \mathrm{i}-\mathrm{q}$ \\
\hline & 18 & $76.2 \mathrm{f}-\mathrm{q}$ & $63.6 \mathrm{u}$ & 49.1 opq & $57.7 \mathrm{~d}-\mathrm{q}$ \\
\hline & 20 & $79.3 \mathrm{~b}-1$ & $69.5 \mathrm{q}-\mathrm{u}$ & $48.2 \mathrm{opq}$ & $52.3 \mathrm{i}-\mathrm{q}$ \\
\hline & 24 & $75.1 \mathrm{~g}-\mathrm{r}$ & $67.5 \mathrm{stu}$ & $51.11-q$ & $52.2 \mathrm{i}-\mathrm{q}$ \\
\hline & 26 & $74.2 \mathrm{i}-\mathrm{s}$ & $72.61-\mathrm{t}$ & $45.6 \mathrm{pq}$ & $50.6 \mathrm{~m}-\mathrm{q}$ \\
\hline \multirow[t]{3}{*}{ PR dominant } & 11 & $79.2 \mathrm{~b}-1$ & $74.1 \mathrm{i}-\mathrm{s}$ & $52.6 \mathrm{~h}-\mathrm{q}$ & $60.3 \mathrm{c}-\mathrm{O}$ \\
\hline & 16 & $74.0 \mathrm{j}-\mathrm{s}$ & $69.0 \mathrm{r}-\mathrm{u}$ & $52.3 \mathrm{~h}-\mathrm{q}$ & $48.4 \mathrm{opq}$ \\
\hline & 22 & $73.2 \mathrm{k}-\mathrm{t}$ & $73.0 \mathrm{k}-\mathrm{t}$ & $47.8 \mathrm{opq}$ & $51.0 \mathrm{~m}-\mathrm{q}$ \\
\hline $\mathrm{KB} / \mathrm{PR}$ dominant & 15 & $71.5 \mathrm{n}-\mathrm{t}$ & $71.5 \mathrm{~m}-\mathrm{t}$ & $45.3 \mathrm{pq}$ & 48.8 opq \\
\hline \multirow[t]{4}{*}{ TF dominant } & 12 & $76.0 \mathrm{f}-\mathrm{q}$ & $77.8 \mathrm{c}-\mathrm{n}$ & $64.8 \mathrm{a}-\mathrm{k}$ & $70.8 \mathrm{a}-\mathrm{d}$ \\
\hline & 19 & $77.6 \mathrm{~d}-\mathrm{n}$ & $77.6 \mathrm{~d}-\mathrm{n}$ & $61.0 \mathrm{c}-\mathrm{O}$ & $63.9 \mathrm{~b}-\mathrm{m}$ \\
\hline & 21 & 79.7 b-k & 82.6 a-f & $52.4 \mathrm{~h}-\mathrm{q}$ & $65.3 \mathrm{a}-\mathrm{k}$ \\
\hline & 25 & $79.5 \mathrm{~b}-\mathrm{k}$ & $80.3 \mathrm{~b}-\mathrm{j}$ & $66.5 \mathrm{a}-\mathrm{g}$ & $65.7 \mathrm{a}-\mathrm{j}$ \\
\hline \multirow[t]{2}{*}{ FF dominant } & 1 & $86.1 \mathrm{ab}$ & $76.0 \mathrm{f}-\mathrm{q}$ & $64.8 \mathrm{a}-1$ & $63.0 \mathrm{~b}-\mathrm{n}$ \\
\hline & 6 & $88.2 \mathrm{a}$ & 83.2 a-e & $65.2 \mathrm{a}-\mathrm{k}$ & $59.0 \mathrm{c}-\mathrm{p}$ \\
\hline $\mathrm{FF} / \mathrm{KB}$ dominant & 2 & $81.0 \mathrm{~b}-\mathrm{i}$ & $71.9 \mathrm{~m}-\mathrm{t}$ & $50.1 \mathrm{n}-\mathrm{q}$ & $52.1 \mathrm{j}-\mathrm{q}$ \\
\hline \multirow[t]{4}{*}{ Unknown } & 5 & $73.2 \mathrm{k}-\mathrm{t}$ & $81.3 \mathrm{a}-\mathrm{g}$ & $60.3 \mathrm{c}-\mathrm{O}$ & $53.8 \mathrm{f}-\mathrm{q}$ \\
\hline & 7 & $73.4 \mathrm{j}-\mathrm{t}$ & $77.9 \mathrm{c}-\mathrm{n}$ & $66.1 \mathrm{a}-\mathrm{h}$ & $63.4 \mathrm{~b}-\mathrm{n}$ \\
\hline & 9 & $76.9 \mathrm{~d}-\mathrm{p}$ & $71.3 \mathrm{n}-\mathrm{t}$ & 47.8 opq & $50.0 \mathrm{n}-\mathrm{q}$ \\
\hline & 27 & $72.41-\mathrm{t}$ & $70.2 \mathrm{p}-\mathrm{u}$ & $53.5 \mathrm{f}-\mathrm{q}$ & $52.9 \mathrm{~g}-\mathrm{q}$ \\
\hline
\end{tabular}

${ }^{\mathrm{z}}$ Dominant species at seeding.

${ }^{\mathrm{y}}$ Product description can be found in Table 1.

${ }^{x}$ Digital images of the plots were collected weekly during the acute drought treatment to estimate the percentage of green cover.

${ }^{\text {w}}$ Means followed by different letters indicate a difference between the products and mowing heights at $P<$ 0.05 in 2017 according to Student's $t$ test.

${ }^{v}$ Means followed by different letters indicate a difference between the products and mowing heights at $P<$ 0.05 in 2018 according to Student's $t$ test.

The results of this research indicate that individual species and their presence within the product at seeding can have a large effect on turfgrass performance during an acute drought treatment. Drought-intolerant species such as PR or drought-escape species such as KB included at various percentages in products can result in overall lawn decline during drought. Products containing TF as the dominant species at seeding performed the best during acute drought, whereas the effects of FF were variable. The benefits of FF were only observed when these species were dominant at seeding. Mowing height also seemed to have affected the green stability during the acute drought treatment and early recovery period. We propose that upper midwestern U.S. consumers who want to decrease their irrigation practices during seasonal drought should choose products with high proportions of TF and FF species and adapt their mowing practices to a higher mowing height during establishment and drought and a shorter mowing height during recovery (after several rainfall events).

\section{Literature cited}

Beard, J.B. 1969. Winter injury of turfgrasses. Proc. First Intl. Turfgrass Res. Conf. 1:226-234.

Bonos, S.A. and J.A. Murphy. 1999. Growth responses, and performance of kentucky bluegrass under summer stress. Crop Sci. 39:770-774, doi: 10.2135/ cropscil999.0011183X003900030026x.

Breuillin-Sessoms, F. and E. Watkins. 2020. Performance of multiple turfgrass species during prolonged heat stress and recovery in a controlled environment. Crop Sci. 60:3344-3361, doi: $10.1002 / \csc 2.20262$.

Carrow, R.N. 2006. Can we maintain turf to customers' satisfaction with less water? Agr. Water Mgt. 80:117-131, doi: 10.1016/j.agwat.2005.07.008\.

Chaves, M., J. Flexas, and C. Pinheiro. 2009. Photosynthesis under drought, and salt stress: Regulation mechanisms from whole plant to cell. Ann. Bot. 103:551560, doi: 10.1093/aob/mcnl25.

Cutulle, M.A., J.F. Derr, D.S. McCall, and B. Horvath. 2013. Impact of hybrid bluegrass, and tall fescue seeding combinations on brown patch severity, and weed encroachment. HortScience 48:493-500, doi: 10.21273/HORTSCI.48.4.493.

Christians, N.E. 2007. Fundamentals of turfgrass management. 3rd ed. Wiley, Hoboken, NJ.

Dacosta, M. and B. Huang. 2006. Changes in carbon partitioning and accumulation patterns during drought and recovery for colonial bentgrass, creeping bentgrass, and velvet bentgrass. J. Amer. Soc. Hort. Sci. 131:484490, doi: 10.21273/JASHS.131.4.484.

Dierking, R.M., C.A. Young, and R.L. Kallenbach. 2012. Mediterranean and continental tall fescue: I. Effect of endophyte status on leaf extension, proline, mono- and disaccharides, fructan, and freezing survivability. Crop Sci. 52:451-459, doi: 10.2135/cropsci2011.03.0159.

Domenghini, J.C., D.J. Bremer, J.D. Fry, and G.L. Davis. 2013. Prolonged drought and recovery responses of kentucky bluegrass and ornamental groundcovers. HortScience 48:1209-1215, doi: 10.21273/ HORTSCI.48.9.1209.

Dukes, M.D. 2012. Water conservation potential of landscape irrigation smart controllers. Trans. ASABE 55:563-569, doi: 10.13031/2013.41391.

Dunn, J.H., E.H. Ervin, and B.S. Fresenburg. 2002. Turf performance of mixtures, and blends of tall fescue, kentucky bluegrass, and perennial ryegrass. HortScience 37:214-217, doi: 10.21273/HORTSCI. 37.1.214. 
Ebdon, J.S. and C.R. Skogley. 1985. Performance of cool season turfgrass in mixture under reduced maintenance botanical composition, p. 275-283. In F. Lemaire (ed.). Proc. Fifth Intl. Turfgrass Res. Conf., Institut National de la Recherche Agronomique, Avignon, France.

Franca, A., A. Loi, and W.J. Davies. 1998. Selection annual ryegrass for adoption to semi-arid condition. Eur. J. Agron. 9:71-78, doi: 10.1016/S1161-0301(98)00024-0.

Friell, J., E. Watkins, and B. Horgan. 2015. Cool-season turfgrass species mixtures for roadsides in Minnesota. Ecol. Eng. 84: 579-587, doi: 10.1016/j.ecoleng.2015. 09.057 .

Friell, J., E. Watkins, B. Horgan, and M. Cavanaugh. 2017. Sod strength characteristics of 51 cool-season turfgrass mixtures. Agron. J. 109:1749-1757, doi: 10.2134/ agronj2016.05.0295.

Fry, J.D. and J.D. Butler. 1989. Responses of tall and hard fescue to deficit irrigation. Crop Sci. 29:1536-1541, doi: $10.2135 /$ cropscil $989.0011183 \times 0029000$ $60045 \mathrm{x}$.

Harrison, C.M. 1931. Effect of cutting and fertilizer applications on grass development. Plant Physiol. 6:669-684, doi: 10.1104/pp.6.4.669.

Huang, B. and H. Gao. 2000. Root physiological characteristics associated with drought resistance in tall fescue cultivars. Crop Sci. 40:196-203, doi: 10.2135/ cropsci2000.401196x.

Huang, B., M. Dacosta, and Y. Jiang. 2014. Research advances in mechanisms of turfgrass tolerance to abiotic stresses: From physiology to molecular biology. Crit. Rev. Plant Sci. 33:141-189, doi: 10.1080/07352689.2014.870411.

Hunt, K.L. and J.H. Dunn. 1993. Compatibility of kentucky bluegrass and perennial ryegrass with tall fescue in transition zone turfgrass mixtures. Agron. J. 85:211-215, doi: 10.2134/agronj1993.000219620085 00020009x.

Jones, G.B., J.B. Alpuerto, B.F. Tracy, and T. Fukao. 2017. Physiological effect of cutting height, and high temperature on regrowth vigor in orchardgrass. Front. Plant Sci. 805, doi: 10.3389/fpls.2017. 00805.

Karcher, D.E. and M.D. Richardson. 2013. Digital image analysis in turfgrass research, p. 1133-1150. In: J.C. Stier, B.P. Horgan, and S.A. Bonos (eds.). Agron. Monogr. 56 Turfgrass: Biology, use, and management. Amer. Soc. Agron, Crop Sci. Soc. Amer., Soil Sci. Soc. Amer., Madison, WI.

Liu, X.Z. and B.G. Huang. 2003. Mowing height effects on summer turf growth, and physiological activities for two creeping bentgrass cultivars. HortScience 38:444-448, doi: 10.21273/HORTSCI.38.3.444.

Macolino, S., G. Pignata, M. Giolo, and M.D. Richardson. 2014. Species succession, and turf quality of tall fescue, and kentucky bluegrass mixtures as affected by mowing height. Crop Sci. 54:1220-1226, doi: $10.2135 /$ cropsci2013.10.0669.

Minnesota Department of Agriculture. 2021. Labeling vegetable and flower seed for home gardeners in Minnesota. 4 Apr. 2021. <https://www.mda.state.mn.us/sites/ default/files/2018-05/2017\%20Labeling $\% 20$ Vegetable $\% 20 \% 26 \% 20$ Flower $\% 20$ Seed $\% 20$ for $\% 20$ Home $\% 20$ Gardeners $\% 20$ in $\% 20$ MN.PDF>.

Morris, K.N. and R.C. Shearman. 2004. A guide to NTEP turfgrass rating. 4 Apr. 2021. $<$ https://ntep.org/pdf/ratings.pdf $>$.

Ozan, L. and K. Alsharif. 2013. The effectiveness of water irrigation policies for residential turfgrass. Land Use Policy 31:378-384, doi: 10.1016/j.landusepol. 2012.08.001.

Park, B.S., H. Samaranayake, and J.A. Murphy. 2017. Response of tall fescue and kentucky bluegrass mixtures to wear. Intl. Turfgrass Soc. Res. J. 13:346-352, doi: 10.2134/itsrj2016.06.0503.

Proctor, C.A., D.V. Weisenberger, and Z.J. Reicher. 2015. Kentucky bluegrass and perennial ryegrass mixtures for establishing Midwest lawns. HortScience 50: 137-140, doi: 10.21273/HORTSCI.50. 1.137.

Rajasekar, S., S.H. Fei, and N.E. Christians. 2006. Analysis of genetic diversity in rough bluegrass determined by RAPD markers. Crop Sci. 46:162-167, doi: 10.2135/ cropsci2005.04-0008.

Reiter, M., J. Friell, B. Horgan, D. Soldat, and E. Watkins. 2017. Drought response of fine fescue mixtures maintained as a golf course fairway. Intl. Turfgrass Soc. Res. J. 13:65-74, doi: 10.2134/itsrj2016. 06.0460 .

Richardson, M.D., D.E. Karcher, K. Highnight, and D. Rush. 2009. Drought tolerance of kentucky bluegrass and hybrid bluegrass cultivars. Appl. Turfgrass Sci., doi: 10.1094/ATS-2009-0112-01-RS.
Rose-Fricker, C., M. Fraser, and W.A. Meyer. 1997. Competitive abilities, and performance of cool season turfgrass species in mixtures in the Willamette Valley of Oregon, USA, under high, and low maintenance conditions. Intl. Turfgrass Soc. Res. J. 8:1330-1335.

Ruemmele, B.A., J.K. Wipff, L. Brilman, and K.W. Hignight. 2003. Fine-leaved Festuca species, p. 129-174. In: M.D. Casler and R.R. Duncan (eds.). Turfgrass biology, genetics, and breeding. Wiley, Hoboken, NJ.

Schneider, C.A., W.S. Rasband, and K.W. Eliceiri. 2012. NIH Image to ImageJ: 25 years of image analysis. Nat. Methods 9:671-675, doi: 10.1038/nmeth.2089.

Soldat, D., G. Obear, B. DeBels, and P. Barak. 2012. Quantifying turfgrass cover with digital image analysis using ImageJ. Amer. Soc. Agron, Crop Sci. Soc. Amer., Soil Sci. Soc. Amer. Intl. Annu. Mtg., 21-24 Oct. 2012, Cincinnati, OH. (abstr.).

Stier, J.C., J. Bae, and G. Jung. 2005. Composition of kentucky bluegrass and perennial ryegrass mixtures subjected to traffic. Intl. Turfgrass Soc. Res. J. 10: 645-653.

Su, K., D.J. Bremer, S.J. Keeley, and J.D. Fry. 2009. Mowing and drought effects on a hybrid bluegrass compared with a kentucky bluegrass. Intl. Turfgrass Soc. Res. J. 11:871-882.

Wang, J.Y., P. Burgess, S.A. Bonos, W.A. Meyer, and B. Huang. 2017. Differential physiological responses, and genetic variations in fine fescue species for heat and drought stress. J. Amer. Soc. Hort. Sci. 142:367-375, doi: 10.21273/JASHS04 121-17.

Wilman, D., Y. Gao, and M.H. Leitch. 1998. Some differences between eight grasses within the Lolium-Festuca complex when grown in conditions of severe water shortage. Grass Forage Sci. 53:57-65, doi: 10.1046/j.1365-2494. 1998.00104.x.

Yachi, S. and M. Loreau. 1999. Biodiversity and ecosystem productivity in a fluctuating environment: The insurance hypothesis. Proc. Natl. Acad. Sci. USA 96:1463-1468, doi: 10.1073/pnas.96.4.1463.

Zhang, C., G.D. Pinnix, Z. Zhang, and G.L. Miller. 2016. Evaluation of key methodology for digital image analysis of turfgrass color using open-source software. Crop Sci. 57:550-558, doi: 10.2135/ cropsci2016.04.0285. 